\title{
Characterization of Specialized Homegardens in Terms of Technology Needs and Techno-Socio- Economic Dimensions
}

\author{
Modem Ravikishore*, Allan Thomas and Rahul Krishnan
}

Dept. of Agricultural Extension, College of Agriculture, Vellayani, Trivandrum, Kerala (695 522), India

\author{
Corresponding Author \\ Modem Ravikishore \\ e-mail:mrks777143@gmail.com
}

\author{
Article History \\ Manuscript No. AR1795 \\ Received in $24^{\text {th }}$ January, 2017 \\ Received in revised form $27^{\text {th }}$ March, 2017 \\ Accepted in final form $6^{\text {th }}$ April, 2017
}

\begin{abstract}
This research paper focuses on characterization of homegardens in terms of technology needs and techno-socio-economic dimensions. The study location was Central Kerala region consisting of Thrissur, Palakkad and Ernakulam districts of India due to the presence of specialized homegarden system. A total of 30 homegarden farmers were selected, to assess the homegardens in terms of technology needs. The study also covered the same Central Kerala region to assess the techno-socio-economic dimensions as perceived by homegarden farmers, Agricultural Officers and Scientists. With respect to technology needs of specialized homegarden farmers, a Chi square test was performed and the interpretation was that, the distribution, by and large had the same technology needs as far as the perception of the farmer was concerned. In general, technology needs of the farmers had radically changed from the conventional ones to those of technologies like scientific storage, processing and value addition of homegarden produces. Technological, economical and socio-cultural dimensions related to the specialized components in homegardens show a variation in priorities between the specialized homegarden farmers and the Agricultural Officers and Scientists. Some of the dimensions which were of high relevance to the homegarden farmers were considered rather insignificant to the other section. Based on the results, it is imperative to identify the dimensions that were perceived to be important to all categories of respondents for providing economic, ecological, social and cultural benefits to the individual farmer and to the community.
\end{abstract}

Keywords: Dimension, farmer, homegardens, technology

\section{Introduction}

Homegardening is an age-old practice in various parts of the world and homegardens play important economic as well as cultural roles in rural societies. These intensive land-use systems involving the deliberate management of multipurpose trees and shrubs (the woody component) grown in intimate association with herbaceous species (mainly annual, perennial, and seasonal agricultural crops), and livestock, are all managed within the compounds of individual homes (Fernandes and Nair, 1986). Thomas and Kurien (2013) identified the main aim of preserving a homegarden is to preserve ritualistic beliefs and cultural identity of joint families. Aravind et al. (2004) concluded that the homegardens which are mimics of mini forests are the forests created by the farmers of Kerala by incorporating various perennial and annual crops which renders the system a dense scenario of vegetation. Zaman et al. (2010) stated that, farmers depend on the naturally growing trees on the homegarden. The modern technologies and extension supports to develop the traditional production systems were almost not available. Allan and Kishore (2016) stated that, maximum technology need was reported for unexploited and under exploited horticultural tree crops which was on par with fruit tree crops (mango and jack) and followed by beverage crops. Processing, value addition and storage requirements were immediate technology needs of the homegarden farmers. Muthuraman (1995) in his article on sustainable agriculture has quoted some dimensions of sustainable agriculture identified by Swaminathan covering the social, economic, technological, political and environmental facets of sustainability as technological appropriability, economic feasibility, economic viability, environmental soundness, temporal stability, resource-use-efficiency, local adaptability, social acceptability, social sustainability, political tacitness, administrative manageability, cultural desirability, renewability, equity and productivity. KAU (2002) identified five dimensions for technology assessment as productivity, adaptability, identity, continuity and security. Small producers, particularly those operating in resource-poor areas and in small holdings (homegarden), have benefited much less from the recent technological breakthrough in agriculture. Identifying the dimensions of technology for homegardens will, thus, enable the future oriented research and development towards need 
based technology for homegardens and effective technology transfer for homegarden farmers. A commonly perceived indicator of homegardens' socioeconomic sustainability is the fact that, homegardens typically contribute towards nutritional security, energy needs and income generation even under conditions of high population densities (Kumar and Nair, 2004). Recently it has been remarked that the concept of socioeconomic sustainability should not only be related to the homegardens' function in the present livelihood conditions, but also to their ability to adjust to socioeconomic changes (Peyre et al., 2006). Zerihun et al. (2011) was of the opinion that home gardening has become an important part of cultural heritage which denotes specific farming practices at different localities. It is, therefore, inappropriate to ascribe definite and effective cultural practices to the management, siting and ownership of home gardening because home gardening has been a way of life for centuries. Thomas and Kurien (2013) identified the main aim of preserving a homegarden is to preserve ritualistic beliefs and cultural identity of joint families. Homegardens are unique agroforestry systems that are often described in detail, but whose characterization in terms of technology needs and techno-socio-economic dimensions have not been extensively studied. Hence, the present study was taken up with the following objectives to assess characterization of homegardens in terms of technology needs and techno-socio-economic dimensions for enhanced economic, ecological and social benefits.

\section{Materials and Methods}

The methodology developed in this study was mainly aiming on the characterization of homegardens in terms of technology needs as perceived by specialized homegarden farmers and techno-socio-economic dimensions as perceived by specialized homegarden farmers, agricultural officers and scientists.

\subsection{Technological needs in specialized homegarden systems as perceived by homegarden farmers}

After the feedback from the farmers during pilot survey and discussion with experts, the researcher came out with some concrete specification regarding various technology/scientific operations that are essential for specialized homegardens. Based on specifications, the study was conducted in Central Kerala region consisting of Thrissur, Palakkad and Ernakulam districts of India due to the presence of specialized homegarden system. A total of 30 homegarden farmers with equal proportion from each district were selected for the study. Specialized homegardens were identified under 'ICAR Niche Area Excellence Project'. Respondents were personally interviewed and data were enumerated from the homegardens with components of specializations so as to get sufficient data for interpretation. The respondents were selected through purposive sampling, that whoever practicing homegardening, those farmers were purposively selected. The technology need assessment was worked out by using score/ rank as stated in Table 1.

The technology needs of farmers vary according to the crops

Table 1: The technology need assessment was worked out by using score/rank

\begin{tabular}{ll}
\hline Score/rank & Criteria \\
\hline 1 & Technology not available (most needed) \\
2 & Technology available but not applicable \\
3 & Technology available but not sustainable \\
4 & Technology available, applicable and sustainable \\
\hline
\end{tabular}

they cultivate, the managerial levels in which they operate, the deficits in the demand and supply of the crops they raise with reference to the specificities of the land they engage for cultivation and the agronomic norms the plant demands. It was with these perspectives; grouping of technology needs of the farmers was done and classified into the aforesaid broad categories. Thus, technology needs scores of all the 30 farmers of the three districts were tabulated and subjected to statistical analysis. The scores assigned being in ordinal scale, the non-parametric test of analysis of variance (chi-square test) was administered to assess the need disparities between the different districts/specialized homegardens.

\subsection{Characterization of specialized homegardens in terms of} technological, social and economic dimensions

Based on the review of literature and detailed discussion with experts, a list of dimensions that appeared to be related with homegarden technologies was prepared. The list of attributes/dimensions was subjected to examination by the homegarden respondents, agricultural officers and scientists/experts located in Central Kerala region consisting of Thrissur, Palakkad and Ernakulam districts of India. They were asked to examine the dimensions critically and also to include additional attributes/dimensions if found necessary. The judges were requested to rate the relevancy of each dimension on a 11-point continuum ranging from most relevant to least relevant with the weightages of 0-10, respectively. The response from all the 30 homegarden respondents, 30 agricultural officers and 18 Scientists/ experts were collected. The selection of the final dimensions of technology in homegardens was based on their proximity values and means of the data collected.

\section{Results and Discussion}

The completed and returned questionnaires from our sample of respondents revealed the results on technological needs in specialized homegardens and techno-socio-economic dimensions as perceived by homegarden respondents, Agricultural officers and scientists.

\subsection{Technological need in specialized homegardens}

The scores recorded from the specialized homegarden farmer based on the available technology were analyzed 
and a frequency distribution for each of the three districts was tabulated. A Chi square test was performed and the interpretations was that, the distribution, by and large had the same technology needs $\left(\chi^{2}=0.598\right)$ as far as the perception of the farmer was concerned (Table 2 ).

\begin{tabular}{lccc}
\hline Table 2: Technological need in specialized homegardens \\
\hline Technology statements & \multicolumn{3}{c}{ Frequency } \\
\cline { 2 - 4 } & Palakkad & Thrissur & Ernakulam \\
\hline $\begin{array}{l}\text { Technology not available } \\
\text { (most needed) }\end{array}$ & 0 & 2 & 0 \\
$\begin{array}{l}\text { Technology available but } \\
\text { not applicable }\end{array}$ & 4 & 2 & 2 \\
$\begin{array}{l}\text { Technology available but } \\
\text { not sustainable }\end{array}$ & 1 & 3 & 3 \\
$\begin{array}{l}\text { Technology available, } \\
\text { applicable and sustain- } \\
\text { able }\end{array}$ & 5 & 3 & 5 \\
\hline
\end{tabular}

In general, technology needs of the farmers had radically changed from the conventional ones to those of technologies like scientific storage, processing and value addition of homegarden produces. This could be due to the higher social and biophysical standards of homegarden respondents of Kerala and the various specialization it incorporates in the limited spatial land resource associated with the homegardens with an intend to maximize returns. Even though the technology needs were the same as far as the perception of the farmers, irrespective of locality, there could be a chance that majority who opined 'Technology available, applicable and sustainable' would be as a result of adequate knowledge on technology before going into some sort of specialization.

3.2. Techno-socio-economic dimensions as perceived by homegarden respondents, agricultural officers and scientists

A detailed and careful perusal of Table 3, showed the technological, economical and socio-cultural dimensions related to the specialized components in homegardens which were rated according to the evaluation by 30 homegareden farmers, 30 agricultural officers and 18 scientists connected to homegarden farming systems. The examination of the results showed a variation in priorities between the specialized homegarden farmers and the agricultural afficers and scientists. Some of the dimensions which were of high relevance to the homegarden farmers were considered rather insignificant to the other section.

In the economic dimensions, the cost of running the specialized components was of utmost importance to the farmers (continuing cost) whereas the point of view of the Agricultural Officers and Scientists was that the prospect of income generation was important. But all the three sections were unanimous in labeling commercialization as the least important economic dimension in relation to the specialized

\begin{tabular}{|c|c|c|c|c|c|c|}
\hline Dimensions & Farmer & Rank & $\mathrm{AO}$ & Rank & Scientists & Rank \\
\hline \multicolumn{7}{|c|}{ A. Economical dimensions } \\
\hline 1. Initial cost & 23.8 & 2 & 27.6 & 2 & 13.6 & 3 \\
\hline $\begin{array}{l}\text { 2. Continuing } \\
\text { cost }\end{array}$ & 24.4 & 1 & 27 & 5 & 13.2 & 4 \\
\hline $\begin{array}{l}\text { 3. Income } \\
\text { generation } \\
\text { potential }\end{array}$ & 20 & 3 & 29.1 & 1 & 14.4 & 1 \\
\hline $\begin{array}{l}\text { 4. Em- } \\
\text { ployment } \\
\text { generation } \\
\text { potential }\end{array}$ & 18.9 & 4 & 20.4 & 6 & 11.8 & 6 \\
\hline $\begin{array}{l}\text { 5. Commer- } \\
\text { cialization }\end{array}$ & 10.5 & 7 & 18.8 & 7 & 11.6 & 7 \\
\hline $\begin{array}{l}\text { 6. Regularity } \\
\text { of returns }\end{array}$ & 16.7 & 5 & 27.1 & 4 & 12.7 & 5 \\
\hline $\begin{array}{l}\text { 7. Rapidity of } \\
\text { returns }\end{array}$ & 16 & 6 & 27.4 & 3 & 14.2 & 2 \\
\hline \multicolumn{7}{|c|}{ B. Technical dimensions } \\
\hline $\begin{array}{l}\text { 1. Physical } \\
\text { compatibility }\end{array}$ & 22.1 & 2 & 25.5 & 4 & 13.1 & 6 \\
\hline 2. Efficiency & 23 & 1 & 23.3 & 9 & 13.3 & 5 \\
\hline 3. Trialability & 19.5 & 8 & 23.2 & 10 & 11.7 & 15 \\
\hline $\begin{array}{l}\text { 4. Complex- } \\
\text { ity }\end{array}$ & 21.6 & 3 & 22.3 & 11 & 12.1 & 13 \\
\hline $\begin{array}{l}\text { 5. Profitabil- } \\
\text { ity }\end{array}$ & 15.1 & 14 & 27 & 1 & 13.3 & 4 \\
\hline $\begin{array}{l}\text { 6. Communi- } \\
\text { cability }\end{array}$ & 14.7 & 15 & 20.4 & 15 & 11.1 & 16 \\
\hline 7. Availability & 16.7 & 12 & 23.5 & 8 & 12.7 & 9 \\
\hline $\begin{array}{l}\text { 8. Decrease } \\
\text { in discomfort }\end{array}$ & 14.6 & 16 & 22 & 12 & 12.5 & 10 \\
\hline 9. Flexibility & 16.5 & 13 & 19.5 & 16 & 12.1 & 12 \\
\hline 10. Simplicity & 17.9 & 10 & 21.9 & 13 & 12.8 & 8 \\
\hline $\begin{array}{l}\text { 11. Observ- } \\
\text { ability }\end{array}$ & 21.1 & 5 & 21.3 & 14 & 11.8 & 14 \\
\hline 12. Viability & 20.8 & 6 & 23.8 & 6 & 13.1 & 7 \\
\hline $\begin{array}{l}\text { 13. Desirabil- } \\
\text { ity }\end{array}$ & 18.1 & 9 & 24 & 5 & 13.4 & 3 \\
\hline 14. Suitability & 19.9 & 7 & 26.6 & 2 & 13.4 & 2 \\
\hline $\begin{array}{l}\text { 15.Local re- } \\
\text { source utili- } \\
\text { zation }\end{array}$ & 21.2 & 4 & 26.5 & 3 & 13.8 & 1 \\
\hline
\end{tabular}

Continue... 


\begin{tabular}{|c|c|c|c|c|c|c|c|c|c|c|c|c|c|}
\hline Dimensions & Farmer & Rank & $\mathrm{AO}$ & Rank & Scientists & Rank & Dimensions & Farmer & Rank & $\mathrm{AO}$ & Rank & Scientists & Rank \\
\hline \multirow{2}{*}{$\begin{array}{l}\text { 16. Availabili- } \\
\text { ty of supplies } \\
\text { and services }\end{array}$} & \multirow[t]{2}{*}{17.5} & \multirow{3}{*}{. } & \multirow[t]{4}{*}{23.5} & \multirow[t]{4}{*}{7} & \multirow[t]{4}{*}{12.5} & \multirow[t]{4}{*}{11} & 3. Attitudes & 24.2 & 3 & 19.4 & 4 & 13.2 & 1 \\
\hline & & & & & & & $\begin{array}{l}\text { 4. Perceived } \\
\text { social status }\end{array}$ & 18.6 & 5 & 18.9 & 5 & 12.2 & 7 \\
\hline \multirow{2}{*}{\multicolumn{3}{|c|}{$\frac{\text { Social dimensions }}{\text { C. Environmental dimensions }}$}} & & & & & 5. Level of & 23.4 & 4 & 20.3 & 3 & 12.6 & 5 \\
\hline & & & & & & & satisfaction & & & & & & \\
\hline $\begin{array}{l}\text { 1. Energy } \\
\text { saving po- } \\
\text { tential }\end{array}$ & 17 & 4 & 22.2 & 2 & 11.8 & 3 & $\begin{array}{l}\text { 6. Scientific } \\
\text { orientation }\end{array}$ & 13.6 & 6 & 23.8 & 2 & 12.5 & 6 \\
\hline $\begin{array}{l}\text { 2. Resource } \\
\text { recycling } \\
\text { capacity }\end{array}$ & 16.1 & 5 & 23.4 & 1 & 12 & 1 & $\begin{array}{l}\text { 7. Percep- } \\
\text { tions of } \\
\text { technology }\end{array}$ & 12.7 & 7 & \multirow[t]{2}{*}{23.8} & \multirow[t]{2}{*}{1} & \multirow[t]{2}{*}{13.1} & \multirow[t]{2}{*}{2} \\
\hline \multirow{2}{*}{$\begin{array}{l}\text { 3. Spatial } \\
\text { threshold }\end{array}$} & \multirow{2}{*}{19.2} & 3 & 211 & 4 & 115 & 4 & F. Decision ma & king dime & ensions & & & & \\
\hline & & & & & $1+. J$ & 4 & 1. Record & 19.2 & 2 & 22.8 & 2 & 12.3 & 4 \\
\hline 4. Availabil- & 19.3 & 2 & 20.1 & 5 & 10.9 & 5 & keeping & & & & & & \\
\hline $\begin{array}{l}\text { ity of raw } \\
\text { materials }\end{array}$ & & & & & & & $\begin{array}{l}\text { 2. Time uti- } \\
\text { lization pat- }\end{array}$ & 19.8 & 1 & 19.6 & 3 & 12.6 & 3 \\
\hline 5. Infrastruc- & 9.9 & 6 & 22.1 & 3 & 11.9 & 2 & & & & & & & \\
\hline $\begin{array}{l}\text { ture develop- } \\
\text { ment }\end{array}$ & & & & & & & $\begin{array}{l}\text { 3. Decision- } \\
\text { making style }\end{array}$ & 13.8 & 4 & 19.3 & 4 & 12.8 & 2 \\
\hline $\begin{array}{l}\text { 6. Sustain- } \\
\text { ability }\end{array}$ & 23.1 & 1 & 16.1 & 6 & 10.9 & 6 & $\begin{array}{l}\text { 4. Extension- } \\
\text { officers' }\end{array}$ & 17 & 3 & 23.2 & 1 & 12.9 & 1 \\
\hline D. Socio-cultur & ral dimen & sions & & & & & influence & & & & & & \\
\hline 1. Social ac- & 24 & 3 & 16.2 & 1 & 10.1 & 2 & G. Human resc & ources din & mension & & & & \\
\hline ceptability & & & & & & & 1. Family & 18.1 & 3 & 15 & 4 & 12.5 & 3 \\
\hline 2. Social & 24.4 & 2 & 14.5 & 2 & 9.7 & 3 & labour & & & & & & \\
\hline $\begin{array}{l}\text { approval } \\
\text { 3. Cultural }\end{array}$ & 24.9 & 1 & 14.4 & 3 & 12.5 & 1 & $\begin{array}{l}\text { 2. Hired la- } \\
\text { bour }\end{array}$ & 17.4 & 4 & 24.8 & 1 & 13.1 & 1 \\
\hline compatibility & & & & & & & 3. Physical & 24.4 & 2 & 22.6 & 3 & 12.2 & 4 \\
\hline E. Psycho-logi & ical dimer & nsions & & & & & labour re- & & & & & & \\
\hline 1. Goals ori- & 25.7 & 2 & 14.8 & 7 & 12.9 & 3 & quirement & & & & & & \\
\hline entation & & & & & & & 4. Skilled & 25.4 & 1 & 23.5 & 2 & 12.7 & 2 \\
\hline $\begin{array}{l}\text { 2. Aspira- } \\
\text { tions }\end{array}$ & 26 & 1 & 14.9 & 6 & 12.9 & 4 & $\begin{array}{l}\text { labour re- } \\
\text { quirement }\end{array}$ & & & & & & \\
\hline
\end{tabular}

component. The farmers point can be substantiated by the fact that most of the specialized homegarden farmers had difficulties in maintaining the components due to the expenses involved. Initial cost could be covered by subsidies but the continuing cost is considered a hindrance. As of the point of Agricultural officers and scientists, the homegarden farmers should realize the income generation potential as it can supplement the continuing cost. Commercialization was ruled out since specialized homegardens had constraints of land, infrastructure, technology, equipment's and financial limitations

Coming to the technical dimensions, all the farmers felt that efficiency, physical compatibility and complexity were the deciding factors, agricultural officers considered profitability, suitability and resource utilization as the major dimensions. Scientists referred that in case of the technical point of view more importance had to be given to local resource utilization, suitability and desirability of the specialized components to the farmer. Farmers view was based on the concept that whichever specialized component he specialized in should be highly efficient and physically compatible with his technical conditions. Profitability was the option selected by the agricultural officers because they were well versed with the accusations about slogans like farming is not profitable and specialized homegardens should have a label of profitability and act as a suitable example for the farming community and for the entire population. Scientists, with their concerns about ecosystem, sustainability and biodiversity took an option of local resource utilization and suitability to the environmental 
aspects.

Under the environmental dimensions farmers felt the need for sustainability and the availability of raw materials for their specialized components, but for Agricultural Officers and Scientists, the need for resource recycling capacity, infrastructure development and the potential to save energy were the primary steps. This was in concordance with the aforementioned conditions.

Cultural compatibility was the major concern for both farmers and scientists in socio-cultural dimensions but agricultural officers felt that social acceptability was more relevant.

From the psychological point of view, farmers felt that aspirations and orientation towards the goal, play a vital role in the specialized homegardens, and Agricultural Officers asserted that perceptions of technology and scientific orientation were the essential qualities. Scientists pointed out that the right attitude towards the farming aspects and the system was of major importance along with good perceptions of technology.

According to the farmers, time utilization was the top priority as it was a major constraint for him but Agricultural Officers and Scientists targeted the influence of extension personnel as the primary dimension as far as decision making was concerned. This was because extension officers with their wide array of skill sets and experience could make the wise and apt decisions for the farmers. Farmer respondents opined that skilled labour was critical in a specialized homegarden along with physical labour requirement. Contrary to that, Agricultural Officers and Scientists considered that hired labour and skilled labour requirements were significant in specialized homegarden situations.

Overall the dimensions which ranked highest between the homegarden farmers, Agricultural Officers and Scientists were initial cost, continuing cost, income generation potential, skilled labour requirement and local resource utilization and the lowest ranks were for commercialization, infrastructure development, family labour, decision making style and communicability.

After critical analysis of all the dimensions, the views of the specialized homegarden farmers, Agricultural Officers and Scientists could be culminated into certain converging and diverging dimensions. These converging and diverging dimensions perceived to be important to the homegarden farmers, Agricultural Officers and Scientists were categorized as high and low by keeping mean as the check. Thus the dimensions perceived to be important to all categories of respondents can be represented with the help of a Venn diagram (Figure 1).

A careful perusal of the Figure 1 showed that 42 dimensions were rated important with mean value as the check. However, only 10 on 42 dimensions were perceived to be important to all categories of respondents (Table 4).

Likewise there was another set of six dimensions that was worthy to be mentioned. They are dimensions that were felt

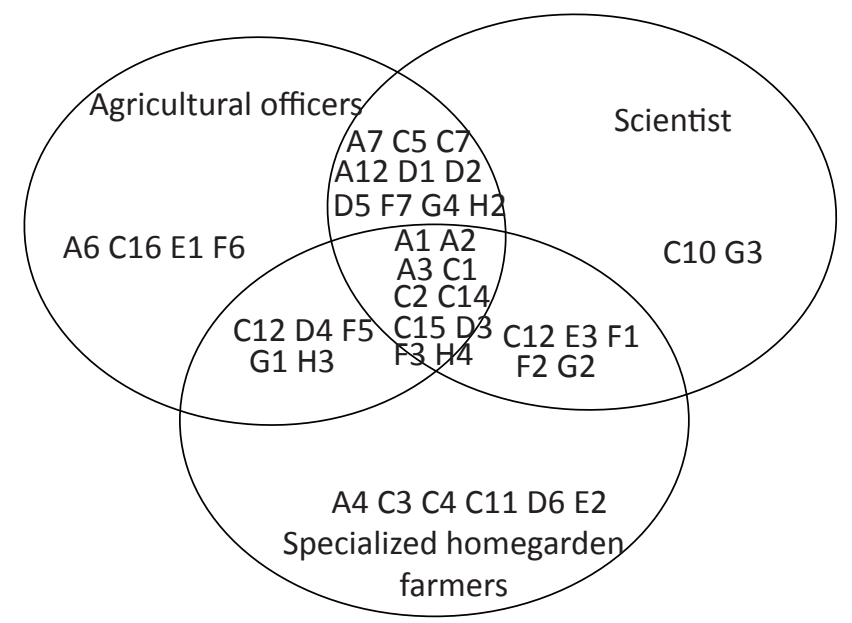

Figure 1: Important 'techno-socio-economic' dimensions as perceived by the homegarden respondents, Agricultural Officers and Scientists

Table 4: Dimensions were perceived to be important to all categories of respondents.

\begin{tabular}{llll}
\hline Sl. No. & Code & Common dimensions & Category \\
\hline 1. & A1 & Initial cost & Economic \\
2. & A2 & Continuing cost & Economic \\
3. & A3 & $\begin{array}{l}\text { Income generation po- } \\
\text { tential }\end{array}$ & Economic \\
4. & C1 & Physical compatibility & Technological \\
5. & C2 & Efficiency & Technological \\
6. & C14 & Suitability & Technological \\
7. & C15 & Local resource utilization & Technological \\
8. & D3 & Spatial threshold & Environmental \\
9. & F3 & Attitude & Psychological \\
10. & H4 & Skilled labour require- & Human \\
& & ment & Resource \\
\hline
\end{tabular}

important by homegarden farmer respondents but which was not that important as perceived by the Agricultural Officers and Scientists. Such dimensions were highlighted in Table 5.

Overall the dimensions mentioned in Table 4 became very

Table 5: Dimensions were perceived to be important to all categories of respondents.

\begin{tabular}{lclr}
\hline Sl. No. & Code & Common dimensions & Category \\
\hline 1. & A4 & $\begin{array}{l}\text { Employment generation } \\
\text { potential }\end{array}$ & Economic \\
2. & C3 & Regularity of returns & Economic \\
3. & C4 & Rapidity of returns & Economic \\
4. & C11 & Observability & Technological \\
5. & D6 & Sustainability & Environmental \\
6. & E2 & Social approval & Social cultural \\
\hline
\end{tabular}


important for specialized homegardens as its inclusion remained largely for more returns for the benefit of the household.

\section{Conclusion}

The distribution, by and large had the same technology needs as far as the perception of the specialized homegarden farmers was concerned. With respect to the techno-socioeconomic dimensions which ranked highest between the homegarden farmers, agricultural officers and scientists were initial cost, continuing cost, income generation potential, skilled labour requirement and local resource utilization and the lowest ranks were for commercialization, infrastructure development, family labour, decision making style and communicability.

\section{References}

Aravind, N., Gandharappa, N.R., Ganeshamoorthy, S., Ibrahim, S., 2004. Homestead agroforestry systems. LEISA INDIA 2004, 21

Fernandes, E.C.M., Nair, P.K.R., 1986. An evaluation of the structure and function of tropical homegardens. Agricultural Systems 21, 279-310.

Gajaseni J., Gajaseni N., 1999. Ecological rationalities of the traditional homegarden system in the Chao Phraya Basin, Thailand. Agroforestry Systems 46, 3-23.

KAU., 2002. Checklist of criteria for assessing agricultural technology development- a reader concept and methodology. In: Prasad, R.M. (Ed.), College of Agriculture, Kerala Agricultural University, Padanakkadu, 15-17.

Kumar, B.M., Nair, P.K.R., 2004. The enigma of tropical homegardens. Agroforestry Systems 61, 135-152.

Muthuraman, P., 1995. Towards sustainable agriculture: dimensions and components. Employment news 20, 1-3.

Peyre, A., Guidal, A., Wiersum, K.F., Bongers, F., 2006. Dynamics of homegarden structure and function in Kerala, India. Agroforestry Systems 66, 101-115.

Thomas, A., Kurien, S., 2013. Homegardens of Kerala: Structural Configuration and Biodiversity. Ind. J. Res. 2(1), 133-135.

Thomas, A., Kishore, K., 2016. Technology needs assessment in the homegarden systems. Journal of Extension Education 27, 5556-5563.

Zaman, S., Siddiquee, S.U., Katoh, M., 2010. Structure and diversity of homegarden agroforestry in Thakurgaon district, Bangladesh. The Open Forest Science Journal 3, 38-44.

Zerihun, K., Weyessa, G., Adugna, D., 2011. Understanding home garden in household food security strategy: case study around Jimma, Southwestern Ethiopia. Research Journal of Applied Sciences 6, 38-43. 